\title{
Articles
}

Central European Review of Economics \& Finance

Vol. 18, No. 2(2017), pp. 19-29. Dol: 10.24136/ceref.2017.006

Luigi Lai ${ }^{1}$

\section{EVOLUTION OF THE SHARE CAPITAL FUNCTION, AS A TOOL FOR OVERCOMING ECONOMIC TURMOIL}

The paper aims at showing that a lower share capital in limited liability companies can be a successful tool for overcoming the consequences of an economic crisis. In a period of economic turmoil insolvency is more than a simple risk. For such a reason the limited liability company shareholders, thanks to the complete financial autonomy given by the share capital, have a shield from the legitimate expectations of the creditors. The share capital protects the entrepreneur and at the same time allows faster fresh starts; nevertheless, in order for that to happen, the share capital cannot be an additional burden, instead has to be a simple formal element.

The article demonstrates that in the last 50 years is visible a shift in the concept and function of the share capital. During the 50's of the past century, the share capital was considered as a guarantee for the company's creditors. Nowadays the European legislators across Europe are heading to consider the share capital as a mere formal element disconnected by any due quantity

JEL Classification Codes: K20, F23.

Keywords: Share capital, European Union, International law, Insolvency.

\section{Introduction}

This article focuses on showing the reader, how the share capital has different functions and how a common approach in Europe is the utmost needed, this common approach in the idea of the author should go in the direction of considering the share capital as a formal element which allows

\footnotetext{
${ }^{1}$ Researcher at National Information Processing Institute - Warsaw - www.opi.org.pl
} 
a perfect independence of the company from the shareholders patrimony. For too many years the share capital has been set in an amount of money quite high; and at the same time the general costs to open a limited liability company were too relevant as well. All the above mentioned drastically discouraged the entrepreneurs to use the limited liability company instrument. Nowadays in Europe governments are going in the direction of lowering such amount of money needed for opening a limited liability company; nevertheless, in the continental civil law countries, the path to lower the share capital level is still faraway. In this article I have taken into consideration the main Italian theories on the function of the share capital, those theories are almost identical to the major theories popular in the majority of countries in continental Europe (Miola, 2005). In this article I show how the Italian legislator is, step by step, abandoning the dogma of a quantitative strong share capital, and it is heading to a share capital considered as a quantitative formality. A formality in the true meaning of the Latin word form, a shape still needed, but just a shape, deprived of any quantitative value. The next step of a future research would be to compare the US System with the EU System, moreover, the article will answer the long-standing question: is still the share capital needed, or is a hoary element that should finally disappear.

Limited liability companies are the back-bone of modern economic systems. If a century ago personal partnerships were the development trigger, nowadays due to the common law influence, personal partnerships are biting the dust. The ratio under this escalation is quite clear, giving the entrepreneur the second chance; in the case of financial distress, the company will be insolvent, but not the shareholder who instead will be protected by the shield of the share capital. Generally, in continental Europe, the share capital was considered as a guaranty to the company creditors. For the reason, the share capital often was a considerable amount of money, which for antonomasia had to be fixed and untouchable by the company so to represent the guaranty, the "treasure” on which a creditor could rely as extrema ratio in the case of company default. Nowadays the share capital has an informative function of declaring the separation between the company capital and the shareholders capital. Nevertheless, previously the share-capital had different functions. The article focus is to show the function of the share capital, and how its function changed during the time. 


\section{Ancient theory of the share capital}

Any business idea to be able to grow and develop also needs financial resources, the share capital has always been recognized as one of the basic factors of production, even before the economic and legal sciences. The share capital is the sum of the shareholders contributions and at the beginning of the company will be equal to the entire amount of the company's assets; nevertheless, later on, these values are no longer the same because the assets will vary according to the performance of the company, while the share capital will always stay the same.

This consideration leads us to analyse the relationships between share capital and company's assets, the company's assets is the set of assets and liabilities that belong to the company; conceptually no different from the assets of a natural person; the difference with the share capital is that the title holder of the assets is the company and not an individual. In such a sense there is a perfect distinction between the company and the shareholders, the company has the so-called financial autonomy; shareholders may lose their shares but in the case of company insolvency they will not get involved. In the first half of the twentieth century, it was prevalent in the doctrine the idea that share capital carried out a function of guaranty in favor of creditors, an illustrious Italian author (Brunetti, 1948) starting from the thought that the use of the company's assets in an economic activity is an essential moment in the framework of the company agreement. The author made descend the idea that the essential characteristic of the contribution of each partner should be productivity. The reasoning then continued with the consideration that the productivity function was, however, carried out by the company assets intended as a whole. A distinctive feature of the share capital would be instead to guarantee the company's creditors, fact justified by the need to balance the effects of the limited liability of the shareholders.

On this basis, it was, therefore, supported the indispensability of the share capital. The capital became, in this perspective, the only way for a company to get credit: since creditors may find satisfaction to eventual claims only on the company's assets, they could calibrate their funding decisions based on the consistency of assurance that they are offered in the form of share capital. This perspective has been the subject of criticism, due to the fact that the guarantee function is carried out, in fact, by the entire company assets and not only by the share capital. Moreover, the share capital provides a brief description of the company's financial of the company situation but is not the direct subject of the guaranty of the creditors, who rather rely on 
earnings forecasts offered by the company and its dynamic situation. It may occur that a company in condition of economic distress has, however, an untouched share capital, in such a sense the guaranty of the share capital is "uncertain, if not illusory"; if the system wanted truly to guarantee the creditors, it should have set restrictions on corporate assets, restrictions, but this restriction if applied, would create the collateral effect to "throw the share company in the most absurd immobility". For the reasons mentioned above, the idea of share capital with a guarantee function has almost been abandoned (Montagnani, 1991).

\section{Productivity function theory}

During the 60's of the past century, some scholars affirmed that the share capital had a productivity function and, only indirectly, a guarantee function for the company creditors (Ambriani, 2012). The share capital, under this theory, allows to achieve and maintain the economic-financial balance of the company and it constitutes the only real "guaranty” of corporate debts. The share capital is, therefore, the "financial skeleton" of the enterprise because it is a financial rule that "binds a the share capital”.

The productive purposes of the share capital are expressed in fact not only at the time the company is formed, where the financial structure was starting but also during the company activity. The guaranty provided by the share capital, This not so radically denied but rather understood in a different way. The guarantee, in fact, is not interpreted in a static sense, ie as directly linked to property forming part of the company's assets, but rather in a dynamic sense. The capital, in other words, does not protect the right of creditors directly but allows that there is still sufficient earnings power by maintaining an appropriate financial structure. This theory has some critical issues, moved mainly by authors who prefer the "nominalistic" conception of the share capital. The productivity approach has also given rise to sub-theories relating to the under capitalization, according to which the amount of the share capital must be appropriate to the company activity. The share capital has an additional function of "budget constraint”; in fact, it is not possible to lower the share capital level under a certain quantity, and it represents sort of bind for the company. 


\section{Nominal function}

The shareholder's participation in the company can be expressed as fractions of capital, the capital itself assumes the role of measurement of the rights and powers which the shareholders have, thereby regulating the conduct of the life of the company as an independent and self-living organization. Even more radically, it is possible to affirm that the presence of the share capital is essential to identify the company organization (Denozza, 2002). This organizational function is based on the nominal capital, not real: in fact, regardless of the qualitative composition of the Company's assets. The organizational function of the capital can be summarized by saying that it serves as a measure to distribute profits among the shareholders. The capital, therefore, is a „pure number” means an accounting entry that expresses quantitatively, a balance of powers in the company, a set of rules that control the powers and ways to have a certain amount of assets always instrumental to the production of wealth.

\section{Informative function}

An important aspect of the share capital is the informative function. The share capital is a signal in case of insolvency when it is possible to notice an excessive imbalance in liabilities and assets. The capital, signaling the approaching insolvency, would act as a "financial safety net" allowing, at least in theory, to prevent it. In other words, the preventive and informative functions are carried out by the nominal capital itself, and by the rules concerning the company assets, allowing the maintaining of an economic and financial stability (Ferrara, 2011).

It is visible the link between the production-function and the information function, which underlines two different aspects of the share capital. The nominal capital is, essentially, what appears on the outside: in fact a nomen, a pure and simple information. This representation consists of a simple number, almost a symbol which is easily comprehensible from the outside of the company. In this light, it is crucial that there are appropriate mechanisms to ensure the representativeness of the capital as information. The share capital, therefore, allows creditors to get an idea about the risk of their investment level, it is indicative of the seriousness of the economic initiative put in place by the shareholders, as it ensures that the contributions are effective, and It summarizes their level of financial commitment. It is also true, however, that lenders are more interested in the company balance sheet, and in 
the dynamics of management. The capital on its own is not able to give this information, or at least is not able to give a sufficient level of details on that.

The informative function finds its general foundation in the provisions under which the companies must indicate the amount of capital (In Italy Article. 2250 of the Italian Civil Code). This provides to third parties, ie at current and potential creditors and, more generally, to the entire market, a summary information regarding the minimum size of the company's assets. Some authors emphasize that the informative value of the share capital reveal that this information is also an expression of an equal treatment of shareholders because the information on the share-capital status protects them from a mis administration of the company board. The share capital allows lenders to understand the real level of risk related to their investment because it is possible to approximatively guess the „seriousness” of the commitment.

Nevertheless, the share capital alone does not provide adequate information on the company real economic situation. First, it summarizes the situation in a single number, then, does not disclose the qualitative composition of assets and liabilities that are part of the company's assets.

It should also be kept in mind the possible time discrepancy: the nominal capital, in fact, may be different from the real economic situation of the company. Shareholders normally have an amount of time (usually until the end of financial year) for the adoption of measures deemed appropriate to re-set the biding level of share capital. In this period, therefore the share capital, it expresses a nominal information that does not correspond to reality.

It seems reasonable to assume that the legislator wanted to enhance the informative function and was not extremely concerned of a possible discrepancy between the reality represented by the capital itself and the reality of the budget itself. In other words, share capital alone does not provide enough information on the true economic situation of the company.

\section{Normative approach - Shareholders considered as different sort of company's creditors}

Some authors recognize in the share capital a regulatory function, which is declined in various shades, and it stresses the importance of the nominal capital. The so-called typological function is expressed in the distinction, within the shareholders, and the creditors. This theory emphasizes a sort of connection between the shareholders and the creditors of the company because what characterizes the shareholder, what confers that status, is the 
ownership of the shares if the share capital. There are authors who believe that the norms which discipline the share capital cannot be interpreted in terms of relationships between shareholders and creditors (Guidotti, Pederzini, 2011). More generally, it denies that the share capital can be seen as part of the contract between the company and its shareholders.

In the opinion of the mentioned authors, it is not true that shareholders have real credit rights against the company. The shareholders indeed have a right to receive back what they have in their time given; However, this right is subject, to a „priority given to the company creditors”(Miola, 2012). Therefore, from a point of "objective" view, share capital is used to determine the amount of wealth on which the shareholders can rely. It has been said that the right of shareholders to have their investments back is subject to conditions The uncertainty of the return, the possibility of complete loss of the amount transferred, are therefore fundamental characteristics. The share capital would, therefore, have a typological function: it constitutes the formal and essential prerequisite of the exercise of economic activities through the corporate form. Without share capital, we could not speak of the company. The share capital also has a regulatory function. According to a part of doctrine, the share capital expresses a need to be, in both quantitative, both qualitatively, because it is a "programmatic element” of the company contract since it is designed to address all the economic activities of the company and to ensure that is carried out correctly. The share capital has a role of protection and development of company activities. Hence it is natural to conclude that the shareholders and the creditors and other third parties the rely on the share capital, and has to be noted that in this setting, what the capital is used for is to check the adequacy of the business program, not its actual implementation (Bartolacelli 2013).

\section{Share capital importance}

The discipline of the law regarding the share capital is a compromise discipline in the positive sense of the term, it has been created a difficult balance between conflicting interests and more generally, between a free-market vision and a more state driven vision. This choice is prevalent in continental Europe law systems and it is strongly rooted in the Italian corporate law (Ewang, 2007). However, the function of the share capital is not a set of immutable principles of corporate law; it is instead the logical order to be reversed. It is not possible to pretend to solve all the problems affecting the 
share capital, with an arbitrarily determination on the function of the share capital, because it is the legal system (i.e. the political side) who determines what is the share capital, and what are the share capital characteristics (Ferri $\mathrm{jr}, 2013)$. It is possible to recognize, in the share capital, liberal roots, since the definition of the share capital balances the principle of liability of the shareholders, allowing to outsource part of the risk of the entrepreneurial activity. A common feature of most schools of thought is represented by the link between the capital and the company's creditors. Most of the legal doctrine in fact, while denying the guaranty function of the capital, has brought the underline a connection between the company and its creditors. This perspective is shared by the Italian and EU legislator since the provisions governing the share capital were originally intended just to protect creditors (Ginevra, 2007).

In general, the share capital is advantageous for creditors of the company since it makes sure that it is kept a patrimonial active, thus ensuring a greater likelihood that the company is going to be solvable. Along with the share capital, reserves also play this role and have often been identified as a "cushion” to defend the real share capital, as an additional safety margin. Therefore, the reserves are an important creditor protection tool, under both aspects, static and dynamic.

The share capital also offers important benefits to the shareholders, and not only to creditors, since it provides the knowledge of a sort short description of the company's balance sheet, (i.e. through its informative function). Without disregarding the important informative value interpreted by the share capital, it is more significant for the company creditors, to know not only the value of the share capital on a certain date but also its evolution over time, so you can take advantage of any positive or negative trends and adjust their investment decisions to them. Those creditors, therefore, have an interest in the set of rules for the establishment, maintenance and the distribution of the shares of the share capital; an error of perspective would be the identification of the conflicting parties, the creditors. As noted above, it would be incorrect to say that the shareholders do not hold any claims against the company. They have precisely the right to see their investment returned, as creditors of the company, but this refund is subject to the prior satisfaction of creditors. The distribution of any profit to the shareholders is linked to the fact that there is an excess of active enough to cover the actual liabilities and capital.

This theory above mentioned might not radically deny the conflict between shareholders and creditors. In addition, company's actions are not always independent from the will of its shareholders, especially in the case of the 
share structures in the narrow base; Also administrators, then, are certainly not always immune from the influence of the shareholders. Therefore, if there was a misalignment of interests between companies, or administrators, and creditors, it could often rely on a divergence between the creditors and the shareholders. Finally, even the fact that creditors and shareholders are to some extent similar (they both finance the company), albeit clearly with differences. We can, therefore, question the effectiveness and efficiency of comparing the share capital with other creditor protection techniques with regard to their convenience, and the possibility to use multiple methods to protects the creditors and the share capital. This leads to consider the efficiency profile of the share capital: in his absence, the "strong" creditors should impose on the company measures to protect their credits. The share capital, protecting creditors, eliminates or at least greatly reduces the number of such transaction costs and also protects the most vulnerable creditors.

This bring us back to the first question of this article, is share capital still needed, or is it just a shadow of the past? In the opinion of the writer, the share capital has the main task of separating the personal assets of the entrepreneur and the company assets. This independence, that the share company has, is the corner stone of the modern economic activities, sort of insurance for the entrepreneur who may rely on that in the case of insolvency, his/her personal assets will not be taken apart and involved in the insolvency procedure of the company. Every entrepreneur has the right to fail and to start again from the beginning. This is very clear in the US system, which has been a leading country in the separation of assets between the company and the entrepreneur. Moreover, the US have been the first state to drastically reduce the share capital obligation, showing the path, that the share capital has to be an important element of a company, but that at the same time, the share capital has to be no more than a formal element. The US system does not consider the share capital as a tool for protecting creditors, it is considered just as an element which allows the assets separation.

\section{References}

Abriani N. et. al. (2012). Diritto delle società - manuale breve, V ed., Milano.

Attanasio F. (2012). S.r.l. semplificata: verso il superamento della nozione di capitale sociale?, in Le Società, p. 897.

Bartolacelli A. (2013). „Novissime” modifiche alla disciplina della s.r.l.s.: saggio minimo di diritto transitorio, in Nuovo Diritto Societario, p. 18

Berk J. And and Demarzo, P. (2011). Finanza aziendale 1, II ed. Torino. 
Booth R. (2000). A Chronology of the Evolution of the Model Business Corporation Act, in Business. Law, 56, p. 63.

Brunetti A. (1948). Trattato del diritto delle società, Milano.

Bukowski S. and Gowers R. (2016). The degree of integration of equity markets in Central Europe (new member EU countries) with the US and UK equity markets, Central European Review of Economics \& Finance No. 1, Vol. 11. Cian M. (2012). S.r.l., s.r.l. semplificata, s.r.l. a capitale ridotto. Una nuova geometria del sistema o un sistema disarticolato?, in Rivista delle. Società, p. 1104.

Denozza F. (2002). A che serve il capitale? Giurisprudenza Commerciale, p. 585.

Denozza F. (2006). Le regole della globalizzazione tra (pretesa) efficienza e (finti) mercati: il caso dei modelli di corporate governance, Giurisprudenza Commerciale, 2006, XXXIII, II, p. 167.

Di Sabato F. (1999). Manuale delle società, Torino.

Ewang F. N. (2007). An Analysis and Critique of the European Union's Minimum Capitalization Requirement, Working Paper Series - Charles Sturt University, p. 1.

Ferrara F. Jr. (2011). Gli imprenditori e le società, Milano.

Ferri G. Jr. (2013). Prime osservazioni in tema di società a responsabilità limitata semplificata e di società a responsabilità limitata a capitale ridotto, Rivista di Diritto. Commerciale, p. 135.

Ginevra E. (2011). Oltre il capitale sociale? Spunti per la ripresa del dibattito sulla riforma della struttura finanziaria delle società di capitali, Torino.

Guidotti R. (2012). La s.r.l. a capitale ridotto, in Trattato di diritto commerciale e di diritto pubblico dell'economia, vol. LXV, Padova

Hamilton R. (2010). Cases and materials on corporations including partnerships and limited liability companies, St. Paul.

Hertig G. (2006). La tutela dei creditori, Diritto societario comparato, Bologna.

Miola M. (2005). Il sistema del capitale sociale e le prospettive di riforma nel diritto europeo delle società di capitali, Rivista delle Società, p. 1199.

Miola M. (2005). La tutela dei creditori ed il capitale sociale: realtà e prospettive, Rivista delle Società, p. 237.

Montagnani C. (1991). Note in tema di riduzione del capitale, Rivista del Notariato, p. 771.

Mustafakulov S. and Khudoykulov K. (2015). Verifying capital asset pricing model in Greek capital market, Central European Review of Economics \& Finance No. 1, Vol. 7. 
Mülbert P. (2002). Legal Capital - Is There A Case Against the European Legal Capital Rules, p. 695.

Niccolini G. (1981). Il capitale sociale minimo, Milano.

Nobili R. (1984). Problemi in tema di riduzione del capitale, in AA. VV., Aumenti e riduzioni di capitale, Milano: Comitato Regionale Notarile Lombardo, Milano, 1984.

Nobili R. (2004). La riduzione del capitale, Trattato delle società per azioni, Torino.

Simonetto E. (1959). Responsabilità e garanzia nel diritto delle società, Padova. 